\title{
Epidemiology of recreational football in Brazil: prevalence and association with risk factors for chronic diseases and self-rated health in adults
}

\author{
Alex Antonio Florindo ${ }^{1}$ \\ José Cazuza de Farias Júnior ${ }^{2}$ \\ Jonathan Charles Kingdon Wells ${ }^{3}$ \\ Pedro Curi Hallal ${ }^{4}$ \\ ${ }^{1}$ Escola de Artes, Ciências e Humanidades, Universidade de São Paulo, SP, Brasil \\ ${ }^{2}$ Departamento de Educação Física, Universidade Federal da Paraíba, João Pessoa, PB, Brasil \\ ${ }^{3}$ Childhood Nutrition Research Centre, Institute of Child Health, London, United Kingdom \\ ${ }^{4}$ Programa de Pós-graduação em Epidemiologia, Universidade Federal de Pelotas, RS, Brasil
}

\begin{abstract}
The aim of this study was to describe the social and health characteristics of adults who practice football for recreation in adult living in Brazil. This was a cross-sectional study using data from the VIGITEL Surveillance System. In 2006, 54,369 interviews were carried out with adults. Individuals were classified in three groups: inactive in leisure-time; recreational football participants: one/ two times per week or three or more times per week. We ran descriptive analysis and binary logistic models. Recreation footballers in Brazil are mostly young men of low schooling levels. The southeastern region had the greatest proportion of practitioners in Brazil. Most footballers practiced once or two times per week (75.9\%), for 60 minutes or more per day $(87.7 \%)$, and used public locations $(94.2 \%)$. Football players had less obesity and poor selfrated health compared with inactive. Football practice seems to provide health and wellbeing benefits, independent of the weekly frequency.
\end{abstract}

Keywords: Epidemiology. Soccer. Recreation. Motor Activity.

\section{Epidemiologia do futebol recreacional no Brasil: prevalência e associação com fatores de risco para doenças crônicas e relato de saúde em adultos}

Resumo: O objetivo deste estudo foi descrever características sociais e de saúde de adultos praticantes de futebol no Brasil. Este foi um estudo transversal que usou dados do Sistema VIGITEL. Em 2006 foram realizadas 54.369 entrevistas. Os indivíduos foram classificados em três grupos: inativos no lazer; praticantes de futebol recreacional: uma/duas vezes por semana ou três ou mais vezes por semana. Foi realizada análise descritiva e modelos de regressão logística. Os praticantes de futebol eram predominantemente jovens e com baixos níveis de escolaridade. A região sudeste teve a maior proporção de praticantes. A maioria praticava uma ou duas vezes por semana $(75,9 \%)$, por 60 minutos ou mais por dia $(87,7 \%)$ e usava espaços públicos $(94,2 \%)$. Os praticantes de futebol tiveram baixa prevalência de obesidade e relato de saúde ruim comparados com os inativos. A prática de futebol contribui para a saúde e bem-estar, independente da frequência semanal de prática.

Palavras-chave: Epidemiologia. Futebol. Recreação. Atividade Motora.

\section{Introduction}

Football is the most popular sport worldwide (DVORAK et al., 2000). For example, the final match of the 2010 World Cup in South Africa was watched by over $85 \%$ of Spain's and $90 \%$ of Holland's populations. Brazil is known as the "country of football" because of its millions of fans all over the country and of its positive results in the World Cup. Previous studies have shown that football is part of the culture in Brazil, and contributes to leisure time entertainment, as well as to the creation of social networks (FRANZINI, 2005; SPAGGIARI, 2008). As a consequence, football is the sport most frequently practiced by children and adolescents (AZEVEDO et al., 2007; HALLAL et al., 2006).

Football is classified as a vigorous-intensity physical activity (AINSWORTH et al., 2000; SHEPHARD, 1999) and its regular practice is associated with a reduction in the risk of chronic diseases, such as hypertension and obesity, along 
with improved physical fitness (KRUSTRUP et al., 2009) and better socialization and wellbeing (SPAGGIARI, 2008). However, epidemiologic data on recreational football players are still limited, particularly in low and middle income countries such as Brazil. This aim of study was described social and health characteristics of practice football for recreation in Brazilian adults.

\section{Methods}

This was a cross-sectional study using data from the Surveillance System of Risk and Protective Factors for Chronic Diseases through Telephone Interviews (VIGITEL), implemented in 2006 by the Brazilian Ministry of Health. In 2006, 54,369 interviews were carried out with adults ( $\geq 18$ years) living in households with a telephone line. The sample was randomly selected, using techniques described elsewhere (MOURA et al., 2008). The response rate of VIGITEL in 2006 was $71.1 \%$. The refusals rate was $9.1 \%$, and in $19.8 \%$ of houses it was not possible the phone contact or the person was not found.

The VIGITEL physical activity questionnaire evaluates the four main domains of physical activity (leisure-time, occupational, transportation and household) in all state capitals and the Federal District in Brazil (FLORINDO et al., 2009a). The questionnaire evaluated the practice of leisure-time physical activity with questions on weekly frequency and daily duration in the previous three months. The questionnaire was validated against 24 hours recall of physical activity, showing acceptable reliability and validity (MONTEIRO et al., 2008).

All estimates presented in this paper use the official weighting factors attributed to each person interviewed, by using the ratio of the number of adults by telephone lines in each household, the relative proportion of categories of sex, age and schooling, as compared to Census data. Details can be obtained in Moura et al. (2008).

For data analyses, individuals were divided into three main groups according to their football practice in leisure time and physical activity behavior: those reporting no involvement in leisure-time physical activity in the previous three months; those reporting recreational football players one or two times per week for at least 30 minutes per day; those reporting recreational football players three or more times per week for at least 20 minutes per day.

Descriptive analyses were undertaken in relation to the participants' social, demographic, lifestyle and disease characteristics, such as sex, age (years), schooling level (years), skin color (white or nonwhite), marital status (with or without partner), region of Brazil where they lived (northern, southern, northeastern, southeastern or central-western region), types of location used for practice (public or private), obesity (body mass index $\geq 30.0 \mathrm{~kg} / \mathrm{m}^{2}$, based on self-reported weight and height), smoking (yes or no) and self-reported health status (very poor/poor or good/very good). Binary logistic regression models were run. The outcome variables were: 1) obesity; 2) smoking; 3 ) self-reported health status. The independent variable was practice of football using those inactive as the reference category. The confounding factors included in the model were sex, age, schooling, transportation, work-related and household physical activity and all others variables when were not dependent (obesity, smoking and self-reported health status). Analyses were run using SPSS version 15.0.

The VIGITEL system was approved by the National Ethical Committee for Research with Humans from the Ministry of Health (number 13081/2008).

\section{Results}

Most $(96.9 \%)$ of the football participants were men, aged $<35$ years $(77.4 \%)$, with $\leq 8$ years of schooling $(54.5 \%)$. Most of them said that their skin color was nonwhite $(69.3 \%)$, and were single $(60.1 \%)$ (Table 1).

The southeastern region had the greatest proportion of practitioners of recreational football in Brazil $(44.0 \%)$, followed by the northeastern region $(25.2 \%)$. On the other hand, the southern region presented the smallest proportion of practitioners of this sport (8.6\%). Among the practitioners of recreational football, most said that they practiced once or twice a week $(75.9 \%)$, for 60 minutes or more per day (87.7\%), in public locations (94.2\%), among which squares and parks were the places most frequently used (66.1\%) (Table 2). 
Table 1. Sociodemographic characteristics of the whole sample and of recreational football players. Brazil, 2006.

\begin{tabular}{|c|c|c|c|c|c|}
\hline & & \multicolumn{2}{|c|}{$\begin{array}{l}\text { Whole } \\
\text { sample }\end{array}$} & \multicolumn{2}{|c|}{$\begin{array}{l}\text { Football } \\
\text { players }\end{array}$} \\
\hline & & $n$ & $\%$ & $n$ & $\%$ \\
\hline \multicolumn{6}{|l|}{ Sex } \\
\hline & Men & 25064 & 46.1 & 5272 & 96.9 \\
\hline & Women & 29305 & 53.9 & 171 & 3.1 \\
\hline \multicolumn{6}{|l|}{ Age (years) } \\
\hline & $18-24$ & 11575 & 21.3 & 2358 & 43.3 \\
\hline & $25-34$ & 13697 & 25.2 & 1854 & 34.1 \\
\hline & $35-44$ & 11586 & 21.3 & 798 & 14.7 \\
\hline & $45-54$ & 8002 & 14.7 & 319 & 5.9 \\
\hline & $55-64$ & 4760 & 8.8 & 112 & 2.0 \\
\hline & 65 or + & 4749 & 8.7 & 2 & 0 \\
\hline \multicolumn{6}{|l|}{ Schooling (years) } \\
\hline & $0-8$ & 28890 & 53.2 & 2963 & 54.4 \\
\hline & $9-11$ & 16273 & 29.9 & 1838 & 33.8 \\
\hline & 12 or + & 9206 & 16.9 & 642 & 11.8 \\
\hline \multicolumn{6}{|l|}{ Skin color* } \\
\hline & White & 22069 & 40.7 & 1668 & 30.7 \\
\hline & Nonwhite & 32262 & 59.3 & 3775 & 69.3 \\
\hline \multicolumn{6}{|l|}{ Marital status } \\
\hline & Single & 28613 & 52.6 & 3272 & 60.1 \\
\hline & Married & 25756 & 47.4 & 2171 & 39.9 \\
\hline Total & & 54.369 & 100 & 5.443 & 100 \\
\hline
\end{tabular}

Table 2. Description of the proportion of the subjects who practiced football $(n=5.443)$.

\begin{tabular}{|c|c|c|}
\hline Variables & $\mathbf{n}$ & $\%$ \\
\hline \multicolumn{3}{|l|}{ Frequency of football practice ${ }^{\star}$} \\
\hline 1 to 2 times/week & 3763 & 75.9 \\
\hline 3 to 4 times/week & 784 & 15.8 \\
\hline 5 or more times/week & 413 & 8.3 \\
\hline \multicolumn{3}{|l|}{ Duration (minutes/day) ${ }^{\star}$} \\
\hline$<30 \mathrm{~min} /$ day & 59 & 1.2 \\
\hline $30-59 \mathrm{~min} /$ day & 552 & 11.1 \\
\hline$\geq 60 \mathrm{~min} /$ day & 4349 & 87.7 \\
\hline \multicolumn{3}{|l|}{ Types of place for physical activity practice ${ }^{\star \star}$} \\
\hline Public & 4037 & 90.2 \\
\hline Private & 439 & 9.8 \\
\hline \multicolumn{3}{|l|}{ Region of Brazil } \\
\hline Northern & 648 & 11.9 \\
\hline Northeastern & 1377 & 25.3 \\
\hline Central-western & 557 & 10.2 \\
\hline Southeastern & 2395 & 44.0 \\
\hline Southern & 466 & 8.6 \\
\hline \multicolumn{3}{|l|}{ Places for practicing football*** } \\
\hline 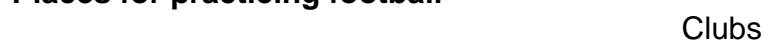 & 153 & 3.4 \\
\hline Gyms & 265 & 5.9 \\
\hline Parks/squares & 2958 & 66.1 \\
\hline Schools & 102 & 2.3 \\
\hline Others & 999 & 22.3 \\
\hline Total & 5443 & 100 \\
\hline
\end{tabular}

The prevalence of obesity was lower in player's football as compared to both inactive individuals. Also, the prevalence of smoking was lower those in the recreational football three or more times per week as compared to inactive subjects. Finally, the prevalence of poor or very poor report of health was lower likely among those practicing football as compared to inactive individuals (Table $3)$. 
Table 3. Prevalence of risk factors from chronic diseases and self-rated health among subjects with different football levels and inactive in leisure time. Brazil, 2006.

\begin{tabular}{lccc}
\hline \multirow{2}{*}{$\begin{array}{l}\text { Risk factors for chronic diseases and } \\
\text { self-rated health }\end{array}$} & $\begin{array}{c}\text { Inactive in leisure- } \\
\text { time }\end{array}$ & $\begin{array}{c}\text { Football 1-2 times } \\
\text { per week }\end{array}$ & $\begin{array}{c}\text { Football 3 or }+ \\
\text { times per week }\end{array}$ \\
\cline { 2 - 4 } & $\%(95 \% \mathrm{Cl})$ & $\%(95 \% \mathrm{Cl})$ & $\%(95 \% \mathrm{Cl})$ \\
\hline Obesity & $12.1(12.7-13.5)$ & $7.4(6.5-8.2)$ & $6.1(4.8-7.7)$ \\
Smoking & $18.4(15.2-16.1)$ & $20.0(18.5-21.2)$ & $17.7(12.8-17.1)$ \\
Poor or very poor self-rated health & $41.6(41.3-42.4)$ & $20.8(18.9-21.6)$ & $22.5(20.7-25.8)$ \\
\hline
\end{tabular}

After adjustment, football players were less likely than inactive individuals to be obese and to report poor or very poor health. Those who reported playing football had a lower risk of obesity, smoking and poor/very poor self-rated health in comparison to inactive individuals (Table 4).

Table 4. Comparison (odds ratios - OR) of risk factors for chronic diseases and self-rated health among subjects with different physical activity levels. Brazil, 2006*.

\begin{tabular}{|c|c|c|c|}
\hline & Obesity*\# & Smoking*\# & Poor self-rated health*\# \\
\hline & OR $(95 \% \mathrm{Cl})$ & OR $(95 \% \mathrm{Cl})$ & OR $(95 \% \mathrm{Cl})$ \\
\hline Inactive in leisure-time & 1 & 1 & 1 \\
\hline Football 1-2 times per week & $\begin{array}{l}0.86 \\
(0.74-0.99)\end{array}$ & $\begin{array}{l}0.83 \\
(0.76-0.92)\end{array}$ & $\begin{array}{l}0.59 \\
(0.54-0.65)\end{array}$ \\
\hline Football 3 or + times per week & $\begin{array}{l}0.82 \\
(0.63-0.97)\end{array}$ & $\begin{array}{l}0.67 \\
(0.56-0.80)\end{array}$ & $\begin{array}{l}0.71 \\
(0.61-0.82)\end{array}$ \\
\hline
\end{tabular}

\section{Discussion}

This study showed that individuals practicing football in Brazil were predominantly young men, with low education; most of them practice the sport in public places. Football players, especially those playing football three or more times per week, were less obese and smokers and to report less poor or very poor health, in comparison with inactive individuals.

Football is the most popular sport in the world (DVORAK et al., 2000; SHEPHARD, 1999) and Brazil is the considered the country of football, because this sport has close relationships with social and cultural aspects of the Brazilian population (FRANZINI, 2005). This is also true in other countries (FOER, 2004). The high media coverage of football, including national teams, but also clubs, contributes to the increasing number of recreational football players (DAMO, 2001).

Our study showed that recreational football was the second most commonly practiced physical activity among Brazilian adults, particularly among younger men $(<35$ years of age) and among those with lower schooling levels ( $\leq 8$ years of schooling). The fact that females were forbidden to practice some sports with physical contact until 60 years ago in Brazil. Perhaps of greater importance, female football practice in Brazil was rare until the 70's, based on the assumption that it could conflicted with ideals of femininity (FRANZINI, 2005; GOELLNER, 2005). Although absolute numbers are still much lower among women as compared to men, it is reassuring that female involvement in football has grown systematically over the last years in Brazil (DA COSTA, 2005; GOELLNER, 2005).

The public places are very important for practice of leisure physical activities in Brazil (FLORINDO et al., 2009a) and in region low socioeconomic level (FLORINDO et al., 2011). The specific places for practice of football are relationship with other types of physical activities as transportation physical activities in men (SALVADOR et al., 2009), because the men, for example, walk more for this places.

The biological benefits of practicing football have been shown in both experimental and 
observational studies (KRUSTRUP et al., 2009; TAIOLI, 2007).

Taioli (2007) analyzed the standardized mortality ratio in 5,389 Italian football formerathletes and showed that cancer mortality and cardiovascular disease mortality were lower in athletes in comparison to the general population. The mortality rate for cancer in athletes was 11.59 $x 100.000$ (compared with mortality rate for cancer of the $35.90 \times 100.000$ in general population) and the mortality rate for diseases of the circulatory system was $10.80 \times 100.000$ (compared with mortality rate for cancer of the $27.11 \times 100.000$ in general population).

An experimental study from Krustrup et al. (2009) compared recreation football players with runners and a control group. There were significant decreases in blood pressure for both groups, but football participants had the largest decreases in fat mass and low density lipoprotein. This is in accordance with our findings showing that recreational football players had a lower prevalence of obesity than those inactive individuals.

Due to the cross-sectional nature of our survey, it is not possible to rule out the possibility of reverse causality, whereby healthier individuals might be more likely to practice recreational football. In spite of that, the prevalence of obesity in football players was smaller than the inactive independent of weekly frequency. The discussion about weekly frequency is important in the field (LEE et al., 2004), but we showed benefits of physical activity practice regardless of the weekly frequency. In the US, a study including 8,421 people during 10 years showed that 'weekend warriors' (energy expenditure of at least 1,000 kilocalories a week in activities such as walking, stair climbing and physical exercises and sports only twice a week), had similar benefits in terms of all cause mortality compared to those practicing physical activity on more than two days. This is in accordance with our findings and suggests that the intermittent metabolic energy expenditure related to football practice is beneficial for health (SHEPHARD, 1999).

Smoking was the only risk factor that all groups of physical activity participants demonstrated lower levels of than those inactive. Previous studies have shown that leisure time physical activity is inversely associated with smoking (DIAS-DA-COSTA et al., 2005; FLORINDO et al., 2009b; ZAITUNE et al., 2007). Our result adds to current knowledge by showing this also extends to football participants.

Football players in our sample also presented better self-rated health in comparison with inactive individuals. A study in Brazil showed that the practice of physical activities in leisure one or two times per week has enjoyment as the main objective (MONTEIRO et al., 2003). This result is very important for both groups of the football players, because self-rated health is associated with quality of life, well-being (MALMBERG et al., 2005). This finding is also analogous to the wellknown association between physical activity and self-reported health (BARROS \& NAHAS, 2001; BARROS et al., 2009; FLORINDO et al., 2009b; MALMBERG et al., 2005; MUKAMAL, 2006).

Besides, a qualitative study in a small city in the São Paulo State showed that recreational football practice in men contributes to the creation of social networks and increases social support (SPAGGIARI, 2008), and supports the notion that football may contribute to better health through psycho-social as well as physiological pathways. Football may be particularly good in this respect as it involves moderate-sized teams who share the experience of training and matches.

Some limitations of this study should be highlighted. First, the results showed associations between some risk factors for chronic diseases and football practice, but not cause-effect relationships, because of its cross-sectional design. Also, due to the low number of women who reported practicing football, care should be exercised before extrapolating our findings to women.

In summary, recreation football players in Brazil are mostly young men of low schooling levels and practicing football in public places. Football practice was associated with reduced prevalence of obesity, smoking and poor selfrated health in Brazilian adults, independent of the weekly frequency. Therefore, football practice seems to provide health and well-being benefits. Since football is a popular sport all over the world, its promotion may have significant impacts on public health, mainly in countries as Brazil.

\section{References}

AINSWORTH, B. E., HASKELL, W. L., WHITT, M. C., IRWIN, M. L., SWARTZ, A. M., STRATH, S. 
J., LEON, A. S. Compendium of physical activities: an update of activity codes and MET intensities.

Medicine \& Science in Sports \& Exercise, Madison, v. 32, suppl. 9, p. 498s-504s, 2000.

AZEVEDO, M. R., ARAUJO, C. L., COZZENSA DA SILVA, M., \& HALLAL, P. C. Tracking of physical activity from adolescence to adulthood: a population-based study. Revista de Saúde Pública, São Paulo, v. 41, n. 1, p. 69-75, 2007.

BARROS, M. B., ZANCHETTA, L. M., MOURA, E. C., \& MALTA, D. C. Self-rated health and associated factors, Brazil, 2006. Revista de Saúde Pública, São Paulo, v. 43, suppl. 2, p. 27s37s, 2009.

BARROS, M. V., \& NAHAS, M. V. Health risk behaviors, health status self-assessment and stress perception among industrial workers.

Revista de Saúde Pública, São Paulo, v. 35, n. 6, p. 554-563, 2001.

DA COSTA, L. P. Atlas do Esporte no Brasil. Rio de Janeiro. Ed. Shape. 2005.

DAMO, A. S. Futebol e estética. São Paulo em Perspectiva, São Paulo, v. 15, n.3, p. 82-91, 2001.

DIAS-DA-COSTA, J. S., HALLAL, P. C., WELLS, J. C., DALTOE, T., FUCHS, S. C., MENEZES, A. M., \& OLINTO, M. T. Epidemiology of leisure-time physical activity: a population-based study in southern Brazil. Cadernos de Saúde Pública, Rio de Janeiro, v. 21, n. 1, p. 275-282, 2005.

DVORAK, J., GRAF-BAUMANN, T., PETERSON, L., \& JUNGE, A. Football, or soccer, as it is called in North America, is the most popular sport worldwide. American Journal of Sports Medicine, Baltimore, v. 28, n.5S, p.1-2, 2000.

FLORINDO, A. A., HALLAL, P. C., MOURA, E. C., \& MALTA, D. C. Prática de atividades físicas e fatores associados em adultos, Brasil, 2006.

Revista de Saúde Pública, São Paulo, v. 43, suppl. 2, p. 65s-73s, 2009a.

FLORINDO, A. A., GUIMARAES, V. V., CESAR, C. L., BARROS, M. B., ALVES, M. C., \& GOLDBAUM, M. Epidemiology of leisure, transportation, occupational, and household physical activity: prevalence and associated factors. Journal of Physical Activity and Health, Champaign, v. 6, n. 5, p. 625-632, 2009 b.

FLORINDO, A. A., SALVADOR, E. P., REIS, R. S., \& GUIMARÃES, V. V. Percepção do ambiente e prática de atividade física em adultos residentes em região de baixo nível socioeconômico.

Revista de Saúde Pública, São Paulo, v. 45, n. 2, p. 302-310, 2011.
FOER, F. Como o futebol explica o mundo. Rio de Janeiro, Jorge Zahar, 2005.

FRANZINI, F. Futebol é "coisa pra macho"? Pequeno esboço para a história das mulheres no país do futebol. Revista Brasileira de História, Rio de Janeiro, v. 25, n. 50, p. 315-328, 2005.

GOELLNER, S. V. Mulheres e futebol no Brasil: entre sombras e visibilidades. Revista Brasileira de Educação Física e Esportes, São Paulo, v. 19, n. 2, p. 143-151, 2005.

HALLAL, P. C., BERTOLDI, A. D., GONCALVES, H., \& VICTORA, C. G. Prevalence of sedentary lifestyle and associated factors in adolescents 10 to 12 years of age. Cadernos de Saúde Pública, Rio de Janeiro, v. 22, n. 6, p. 1277-1287, 2006.

KRUSTRUP, P., NIELSEN, J. J., KRUSTRUP, B. R., CHRISTENSEN, J. F., PEDERSEN, H., RANDERS, M. B., BANGSBO, J. Recreational soccer is an effective health-promoting activity for untrained men. British Journal of Sports Medicine, Loughborough, v. 43, n. 11, p. 825-831, 2009.

LEE, I. M., SESSO, H. D., OGUMA, Y., \& PAFFENBARGER, R. S., JR. The "weekend warrior" and risk of mortality. American Journal of Epidemiology, Baltimore, v. 160, n. 7, p. 636641, 2004.

MALMBERG, J., MIILUNPALO, S., PASANEN, M., VUORI, I., \& OJA, P. Characteristics of leisure time physical activity associated with risk of decline in perceived health--a 10-year follow-up of middle-aged and elderly men and women.

Preventive Medicine, v. 41, n. 1, p. 141-150, 2005.

MONTEIRO, C. A., CONDE, W. L., MATSUDO, S. M., MATSUDO, V. R., BONSENOR, I. M., \& LOTUFO, P. A. A descriptive epidemiology of leisure-time physical activity in Brazil, 1996-1997.

Pan American Journal of Public Health, Washington, v. 14, n. 4, p. 246-254, 2003.

MONTEIRO, C. A., FLORINDO, A. A., CLARO, R. M., \& MOURA, E. C. Validity of indicators of physical activity and sedentariness obtained by telephone survey. Revista de Saúde Pública, São Paulo, v. 42, n. 4, p. 575-581, 2008.

MOURA, E. C., NETO, O. L. M., MALTA, D. C., MOURA, L. D., SILVA, N. N. D., BERNAL, R., MONTEIRO, C. A. Surveillance of risk-factors for chronic diseases through telephone interviews in 27 Brazilian cities (2006). Revista Brasileira de Epidemiologia, São Paulo, v. 11, suppl. 1, p. 20s37s, 2008. 
MUKAMAL, K. J. Alcohol consumption and selfreported sunburn: a cross-sectional, populationbased survey. Journal of the American

Academy of Dermatology, St. Louis, v. 55, n. 4, p. 584-589, 2006.

SALVADOR, E. P., REIS, R. S., \& FLORINDO, A. A. A prática de caminhada como forma de deslocamento e sua associação com a percepção do ambiente em idosos. Revista Brasileira

Atividade Física e Saúde, Londrina, v. 14, n. 3 , p. 197-205, 2009.

SHEPHARD, R. J. Biology and medicine of soccer: an update. Journal of Sports Science, Abingdon, v. 17, n. 10, p. 757-786, 1999.

SPAGGIARI, E. Ganhar jogo, pagar jogo e ganhar visita: prática futebolística em um bairro rural.

Horizontes antropológicos, Porto Alegre, v. 14, n. 30, p. 165-190, 2008.

TAIOLI, E. All causes of mortality in male professional soccer players. European Journal of Public Health, Stockholm, v. 17, n. 6, p. 600604, 2007.

ZAITUNE, M. P., BARROS, M. B., CESAR, C. L., CARANDINA, L., \& GOLDBAUM, M. Variables associated with sedentary leisure time in the elderly in Campinas, Sao Paulo State, Brazil. Cadernos de Saúde Pública, Rio de Janeiro, v. 23, n. 6, p. 1329-1338, 2007.

O presente artigo faz parte de uma análise do banco de dados do Sistema VIGITEL (Vigilância de fatores de risco e proteção para doenças crônicas por inquérito telefônico) do Ministério da Saúde do Brasil do ano de 2006. Este inquérito é feito anualmente nas 26 capitais brasileiras mais o Distrito Federal pelo Ministério da Saúde desde o ano de 2006 com pessoas adultas que residem em domicílios com linha de telefone fixo. Um dos indicadores de saúde pesquisados pelo sistema é a prática de atividade física. Portanto, o presente artigo objetivou fazer uma análise detalhada dos praticantes de futebol do Brasil utilizando dados deste sistema.

\section{Endereço:}

Alex Antonio Florindo

USP - Escola de Artes, Ciências e Humanidades

Rua Arlindo Bettio, 1000 Ermelino Matarazzo

São Paulo SP Brasil

03828-000

Telefone: +55 11 3091-8157

e-mail: aflorind@usp.br

Recebido em: 25 de novembro de 2011.

Aceito em: 18 de fevereiro de 2013.

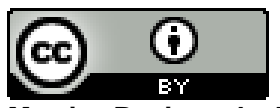

Motriz. Revista de Educação Física. UNESP, Rio Claro, SP, Brasil - elSSN: 1980-6574 - está licenciada sob Creative Commons - Atribuicão 3.0 